\title{
Peningkatan Pemahaman Tentang Politik Uang Bagi Pemilih Pemula Di Kecamatan Kuala Pesisir Kabupaten Nagan Raya
}

\author{
Fadhil Ilhamsyah \\ Jurusan Ilmu Administrasi Negara, Universitas Teuku Umar \\ Email: fadhil.ilhamsyah@utu.ac.id
}

\begin{abstract}
Elections as a mechanism for democracy are important events, where the people are again asked for blessing by politicians to become their 'representatives' in the government. In the election, candidates and political parties compete to win the sympathy of voters. To fight for one of the seats in the government, various efforts were made by these political parties. Money politics is one of the ways to achieve this. Money politics is the giving of money or goods so that during elections someone uses their right to vote in a certain way. The purpose of this community empowerment is to increase understanding of the money politics of voters, especially new voters, who are expected to become smart, honest, fair, secret voters and choose according to their conscience. The implementation method is a combined lecture using laptop and LCD media to display material power points on money politics comprehensively and display examples of images of forms of money politics that often occur in Indonesia. The results of this activity Students of Kuala Pesisir State Vocational School 1 as first-time voters have an understanding of the dangers and effects of money politics in the Election, and after this activity Students of Kuala Pesisir State Vocational School 1 as voters can honestly use their voting rights in the 2019 Election, just, free and secret according to his conscience.
\end{abstract}

Keywords: Understanding, Money Politics, Beginner Voters

\begin{abstract}
Abstrak
Pemilu sebagai sebuah mekanisme dalam berdemokrasi merupakan peristiwa penting, dimana rakyat kembali dimintai restu oleh politisi untuk menjadi 'wakilnya' di dalam pemerintahan. Di dalam Pemilu para kandidat dan Partai Politik bersaing untuk mendapatkan simpati pemilih. Untuk memperebutkan salah satu kursi di pemerintahan, berbagai upaya dilakukan oleh parpol-parpol tersebut. Politik uang merupakan salah satu cara yang dilakukan untuk mewujudkan hal tersebut. Politik uang merupakan pemberian uang atau barang supaya disaat pemilu seseorang menggunakan hak pilihnya dengan cara tertentu. Tujuan pemberdayaan masyarakat ini untuk meningkatkan pemahaman tentang politik uang para pemilih terutama pemilih pemula diharapkan dapat menjadi pemilih yang cerdas, jujur, adil, rahasia dan memilih sesuai hati nuraninya. Metode pelaksanaan adalah ceramah dikombinasikan dengan memanfaatkan media laptop dan LCD untuk menampilkan power point materi mengenai politik uang secara komprehensif serta menampilkan contoh gambar bentuk-bentuk politik uang yang sering terjadi di Indonesia. Hasil dari kegiatan ini Siswa/i SMK Negeri 1 Kuala Pesisir sebagai pemilih pemula memiliki pemahaman tentang bahaya dan dampak politik uang dalam Pemilu, dan setelah kegiatan ini Siswa/i SMK Negeri 1 Kuala Pesisir sebagai pemilih dapat menggunakan hak suaranya dalam Pemilu 2019 dengan jujur, adil, bebas dan rahasia sesuai hati nuraninya.
\end{abstract}

Kata Kunci : Pemahaman, Politik Uang, Pemilih Pemula

\section{Pendahuluan}

Pemilu sebagai sebuah mekanisme dalam berdemokrasi merupakan peristiwa penting, dimana rakyat kembali dimintai restu oleh politisi untuk menjadi 'wakilnya' di dalam pemerintahan. Di dalam Pemilu para kandidat dan Partai Politik bersaing untuk mendapatkan simpati pemilih. Persaingan ini, idealnya kemudian 
menjadi penentu dan berpengaruh terhadap pilihan kebijakan Pemerintah, karena Kandidat dan Partai akan menerapkan pilihan kebijakan yang sesuai dengan platform yang mereka bangun. Karena adanya persaingan di dalam pemilu di mana beberapa kandidat bersaing untuk mendapatkan posisi pada suatu lembaga pemerintahan, pemilu kemudian juga berdampak pada pilihan kebijakan yang akan dibuat oleh sebuah lembaga pemerintahan.

Pemilu menjadi sangat penting dalam kehidupan bernegara karena rakyat harus memilih kandidat dan partai yang dapat benar-benar membawa aspirasi dan kepentingan dalam formulasi kebijakan pemerintahan nantinya.

Sebagai sebuah mekanisme, Pemilu kemudian diharapkan dilaksanakan secara bebas dan setara ( free and fair), dimana sistem pemilu menjamin hak individu dan adanya sistem kontrol bagi menajemen pelaksanaan pemilu. Sukses dari pemilu kemudian ditentukan oleh penerimaan dari seluruh partisipan pemilu (partai politik dan kandidat) secara bulat (legitimate) dan mengikat (binding.

Secara normatif, Pemilihan Umum (Pemilu) adalah plebisit raya untuk memilih para pejabat yang akan duduk dalam lembaga-lembaga perwakilan rakyat, perwakilan daerah, dan pucuk pimpinan eksekutif. Namun secara diskursus ilmu politik, Pemilu sendiri merupakan ajang perebutan kekuasaan yang dilembagakan, yang melibatkan kelompok-kelompok politik dan yang merupakan cerminan dari tumbuhnya perikehidupan politik dalam masyarakat politik.

Perebutan kekuasaan akan berlangsung lebih dramatis bila melibatkan antara mereka yang sedang berkuasa (incumbent) di satu kubu, serta berhadapan dengan mereka yang mengail dalam peruntungan politik (challenge) di kubu yang lain. Praktek di lapangan menunjukkan, dalam perebutan kekuasaan tersebut para pihak cenderung "menghalalkan segala cara" atau melakukan "perbuatan melawan hukum".

Dari setiap Pemilu dan Pilkada di Indonesia selalu menghadirkan pertarungan yang cukup sengit diantara partai-partai politik dan kandidat yang ikut meramaikan kontestasi Pemilu dan Pilkada. Untuk memperebutkan salah satu kursi di pemerintahan, berbagai upaya dilakukan oleh parpol-parpol tersebut. Politik uang merupakan salah satu cara yang dilakukan untuk mewujudkan hal tersebut. Politik uang merupakan pemberian uang atau barang supaya disaat pemilu 
seseorang menggunakan hak pilihnya dengan cara tertentu. Politik uang ini merupakan pelanggaran dalam kampanye yang dapat menyebabkan nilai demokrasi meluntur. Lebih lanjut Gary Goodpaster dalam studinya mendefinisikan politik uang dalam konteks norma hukum Pemilu. Dalam studinya, Ia mendefinisikan politik uang sebagai bagian dari korupsi yang terjadi dalam proses-proses Pemilu, yang meliputi pemilihan presiden, kepala daerah, dan pemilu legislatif. Gary Goodpaster, kemudian menyimpulkan bahwa politik uang merupakan transaksi suap-menyuap yang dilakukan oleh aktor untuk kepentingan mendapatkan keuntungan suara dalam pemilihan (Gary Goodpaster, 2001 : 4).

Tidak dapat dipungkiri, politik uang dilakukan hampir disetiap daerah di Indonesia. Politik uang pun telah dianggap oleh para pemilih sebagai tradisi yang akan selalu hadir disaat setiap Pemilu dan Pilkada. Politik uang pun diyakini sebagai kesempatan emas untuk mendapatkan rejeki yang tak diduga-duga.

Praktik politik uang terjadi dengan pola yang beragam dalam Pilkades, Pilkada, Pemilu legislatif, dan Pemilu Presiden. Dari segi caranya, menurut Wahyudi Kumorotomo, pola politik uang dalam Pilkada langsung terjadi secara langsung dan secara tidak langsung. Pola langsung meliputi (1) pembayaran tunai dari tim sukses calon kepada konstituen potensial, (2) sumbangan dari bakal calon kepada Parpol yang telah mendukungnya, (3) sumbangan wajib yang disyaratkan oleh parpol kepada kader partai atau bakal calon yang akan mencalonkan diri sebagai kepala daerah. Politik uang secara tidak langsung bisa berbentuk pembagian hadiahatau doorpize, sumbangan sembako kepada konstituen, pembagian semen di daerah pemilihan (Ahsan Jamet Hamidi dkk, 2008 : 49).

Berdasarkan aktor dan wilayah operasinya, Didik Supriyanto (2008) mengemukakan bahwa politik uang dalam Pilkada dapat dibedakan menjadi empat lingkaran, yaitu (1) lingkaran satu, transaksi antara elit ekonomi (pemilik uang) dengan pasangan calon kepala daerah, (2) lingkaran dua, transaksi antara pasangan calon kepala daerah dengan partai politik yang mempunyai hak untuk mencalokan, (3) lingkaran tiga, transaksi antara pasangan calon dan tim kampanye dengan petugaspetugas Pilkada yang mempunyai wewenang untuk menghitung perolehn suara, dan (4) lingkaran empat, transaksi antara calon dan tim kampanye dengan massa pemilih (pembelian suara). lingkaran empat tersebut dilakukan dalam berbagai bentuk, antara lain pemberian ongkos transportasi kampanye, janji membagi 
uang/barang, pembagian sembako atau semen untuk membangun tempat ibadah, serangan fajar, dan lain-lain.

Tak jauh berbeda dengan temuan pola politik uang di tempat lain, pola praktik politk uang dalam Pilkada DKI Tahun 2012 terdiri atas tiga pola, yaitu pembayaran tunai, pascabayar dan melibatkan pemilih sebagai relawan. Ketiga pola ini menggunakan uang atau barang sebagai imbalan untuk pemilih atau masyarakat dari pasangan kandidat atau tim suksesnya. Politik uang secara tunai dilakukan oleh pasangan calon dan tim sukses dengan cara memberikan sejumlah uang atau benda bernilai uang kepada pemilih. Pemberian uang terutama dilakukan dalam bentuk serangan fajar di saat menjelang hari pemilihan. Politik uang cara pascabayar, yaitu pemberian uang dari kandidat kepada sekelompok orang setelah dilaksanakan hari pemungutan suara jika mendapatkan jumlah suara sesuai target. Bila melebihi target, maka dana yang diterima oleh kelompok orang ini bertambah sesuai kelipatannya. Sedangkan pola pelibatan pemilih sebagai relawan tim sukses dan pasangan calon merupakan modus menggerakkan pemilih secara sistematis dengan imbalan sejumlah uang (Tim Peneliti KPU Bandung Barat, 2014 : 12).
Praktek politik uang ini juga dapat memberikan dampak buruk bagi masyarakat. Karena para kandidat yang terpilih pasti akan berfikir untuk mengembalikan modal yang telah dikeluarkannya selama Pemilu termasuk biaya politik uang. Maka tidak jarang kita lihat korupsi banyak dilakukan oleh para pejabat-pejabat yang terpilih dalam Pemilu atau Pilkada.

Politik uang dalam UndangUndang Nomor 7 Tahun 2017 Tentang Pemilihan Umum dikategorikan dalam pelanggaran pemilu dan tindak pidana pemilu. Ketentuan tentang politik uang dijelaskan dalam Pasal 515 UU 7 Tahun 2017 “ Setiap orang yang dengan sengaja pada saat pemungutan suara menjanjikan atau memberikan uang atau materi lainnya kepada Pemilih supaya tidak menggunakan hak pilihnya atau memilih Peserta Pemilu tertentu atau menggunakan hak pilihnya dengan cara tertentu sehingga surat suaranya tidak sah, dipidana dengan pidana penjara paling lama 3 (tiga) tahun dan denda paling banyak Rp 36.000.000 (tiga puluh enam juta rupiah)".

Ketentuan lebih lanjut dijelaskan dalam Pasal 523 UU 7 Tahun 2017 sebagai berikut :

1. Setiap pelaksana, peserta, dan/atau tim Kampanye Pemilu yang dengan sengaja menjanjikan atau memberikan 
uang atau materi lainnya sebagai imbalan kepada peserta Kampanye Pemilu secara langsung ataupun tidak langsung sebagaimana dimaksud dalam Pasal 280 ayat (1) huruf j dipidana dengan pidana penjara paling lama 2 (dua) tahun dan denda paling banyak Rp 24.000.000 (dua puluh empat juta rupiah).

2. Setiap pelaksana, peserta, dan/atau tim Kampanye Pemilu yang dengan sengaja pada Masa Tenang menjanjikan atau memberikan imbalan uang atau materi lainnya kepada Pemilih secara langsung ataupun tidak langsung sebagaimana dimaksud dalam Pasal 278 ayat (2) dipidana dengan pidana penjara paling lama 4 (empat) tahun dan denda paling banyak $R p$ 48.000.000 (empat puluh delapan juta rupiah).

3. Setiap orang yang dengan sensaja pada hari pemungutan suara menjanjikan atau memberikan uang atau materi lainnya kepada Pemilih untuk tidak menggunakan hak pilihnya atau memilih Peserta Pemilu tertentu dipidana dengan pidana penjara paling lama 3 (tiga) tahun dan denda paling banyak $\mathrm{Rp} 36.000 .000$ (tiga puluh enam juta rupiah).

Oleh karena itu, untuk mengurangi kecurangan dalam Pemilu terutama praktek politik uang maka Panwaslu Kecamatan Kuala Pesisir melaksanakan Sosialisasi Pelanggaran Pemilu Tentang Politik Uang bagi pemilih terutama bagi pemilih pemula sangat penting dilakukan. Dengan adanya pemahaman tentang politik uang para pemilih terutama pemilih pemula diharapkan dapat menjadi pemilih yang cerdas, jujur, adil, rahasia dan memilih sesuai hati nuraninya.

\section{METODE PELAKSANAAN}

Kegiatan ini dilakukan dengan melihat pengalaman pada pelaksanaan Pemilu dan Pemilukada sebelumnya, bahwa praktek politik uang menjadi salah satu pelanggaran Pemilu yang paling banyak terjadi di Kecamatan Kuala Pesisir. Praktek ini bukan hanya terjadi karena adanya upaya pemberian uang atau barangbarang lainnya para kandidat atau partai politik melainkan juga adanya penerimaan dari masyarakat terhadap pemberian tersebut. Tidak adanya sikap penolakan dari masyarakat menunjukkan rendahnya pemahaman para pemilih termasuk pemilih pemula terhadap bahaya dan dampak politik uang pada saat Pemilu. Oleh karena itu, penting diadakan suatu 
pelaksanaan pengabdian masyarakat yang telah dilaksanakan pada 29 Maret 2018, untuk memperkenalkan apa itu politik uang, bentuk dan pola politik uang, bahaya dan dampak politik uang setelah Pemilu serta sanksi yang akan didapat oleh pemberi dan penerima politik uang dalam Pemilu serentak tahun 2019.

Yang menjadi sasaran dari kegiatan ini adalah para Siswa/i SMK Negeri 1 Kuala Pesisir yang telah berumur 17 tahun. Pemilihan ini didasarkan bahwa mereka adalah para pemilih yang akan pertama kali menggunakan hak pilihnya pada Pemilu serentak tahun 2019. Sebagai pemilih pemula yang masih labil dalam menentukan pilihannya, tentu menjadi sangat rawan untuk dijadikan sasaran praktek politik uang. Oleh sebab itu, perlu diberikan pemahaman tentang politik uang agar kiranya para Siswa/i ini dapat menjadi salah satu elemen masyarakat yang akan menolak adanya praktek politik uang.

Proses pelaksanaan sosialisasi ini dilakukan dengan metode ceramah dan diskusi terhadap materi yang disampaikan. Ceramah dilakukan untuk memaparkan konsep-konsep mengenai politik uang, bentuk dan pola politik uang, bahaya dan dampak politik uang setelah Pemilu serta sanksi yang akan didapat oleh pemberi dan penerima politik uang dalam Pemilu serentak tahun 2019.
Metode ceramah dikombinasikan dengan memanfaatkan media laptop dan LCD untuk menampilkan power point materi mengenai politik uang secara komprehensif serta menampilkan contoh gambar bentukbentuk politik uang yang sering terjadi di Indonesia.

\section{HASIL DAN PEMBAHASAN}

Keberhasilan target peserta sosialisasi. Target peserta kegiatan sosialisasi pelanggaran pemilu ini dinilai cukup baik, dengan melihat kehadiran peserta di atas 30 orang. Jumlah ini menunjukkan bahwa hampir keseluruhan Siswa/i SMK Negeri 1 Kuala Pesisir yang telah berumur 17 tahun ikut serta dalam kegiatan sosialisasi ini.

Target Penyampaian Materi. Materi dapat disampaikan dengan baik melalui pemanfaatan LCD dan praktik langsung kepada peserta. Adapun materi yang disampaikan adalah: (a) Definisi politik uang, (b) Bentuk dan pola politik uang, (c) Pandangan masyarakat terhadap politik uang, (d) Dampak politik uang, dan (f) Sanksi politik uang dalam Pemilu tahun 2019.

Ketercapaian tujuan sosialisasi. Secara keseluruhan tujuan sosialisasi dapat tercapai dengai baik. Materi yang disampaikan pemateri dapat diterima secara baik oleh peserta sosialisasi dengan adanya antusiame 
peserta dalam sesi tanya-jawab. Disamping itu dengan adanya penyampaian menngenai bahaya, dampak dan sanksi dari praktek politik uang telah memberikan kesadaran bagi peserta untuk tidak terlibat dalam praktek politik uang dan akan lebih aktif untuk terlibat dalam pengawasan terhadap praktek politik uang di kawasan Kecamatan Kuala Pesisir Kabupaten Nagan Raya.

\section{PENUTUP}

Hasil yang dicapai melalui kegiatan pengabdian masyarakat ini adalah sebagai berikut :

1. Siswa/i SMK Negeri 1 Kuala Pesisir sebagai pemilih pemula memiliki pemahaman tentang bahaya dan dampak politik uang dalam Pemilu.

2. Siswa/i SMK Negeri 1 Kuala Pesisir sebagai pemilih dapat menggunakan hak suaranya dalam Pemilu 2019 dengan jujur, adil, bebas dan rahasia sesuai hati nuraninya.

3. Memotivasi Siswa/i SMK Negeri 1 Kuala Pesisir agar dapat menjadi agen pengawasan partisipatif terhadap pelanggaran politik uang di kawasan Kecamatan Kuala Pesisir Kabupaten Nagan Raya.

Praktik politik uang dalam pemilu dapat dihindari dan diminimalisir dengan adanya keterlibatan masyarakat yang menjadi pemilih khususnya pemilih pemula dalam melakukan penolakan terhadap berbagai upaya pemberian politik uang oleh para kandidat atau partai politik. Selain itu, sosialisasi tentang politik uang kepada pemilih perlu terus digalakkan oleh penyelenggara Pemilu dan Stakeholder terkait agar masyarakat memiliki pemahaman yang komprehensif terhadap bahaya dan dampak politik uang dalam Pemilu.

\section{DAFTAR PUSTAKA}

Ahsan Jamet Hamidi, dkk. 2008. Pemilu Tidak Bebas Politik Uang. Jakarta :

Didik Supriyanto, Transkrip Diskusi Publik Terbatas,

(ijrsh.files.wordpress.com/2008/0

6/politik-uang-dalam-pilkada.pdf ( diakses, 20-03-2018).

Gary Goodpaster. 2001. Refleksi tentang Korupsi di Indonesia. Jakarta: USAID.

Tim Peneliti KPU Bandung Barat. 2014. Praktek Politik Uang Pada Pemilu Legislatif 2014 : Studi Kasus Di Kabupaten Bandung Barat. Bandung Barat : KPU Bandung Bandung Barat.

Undang-Undang Nomor 7 Tahun 2017 Tentang Pemilihan Umum 